\title{
NAPJAINK HOLLANDIAI MŰVÉSZETI NEVELÉSE: KIÉ A TANTERV?
}

\section{CONTEMPORARY ARTS EDUCATION IN THE NETHERLANDS: WHO OWNS THE CURRICULUM?}

\author{
Viola van Lanschot Hubrecht, Nienke Nieveen \\ tantervi szakértók \\ Instituut voor Leerplanontwikkeling/Netherlands Institute for Curriculum Development (SLO) ${ }^{2}$, Hollandia
}

\begin{abstract}
ÖSSZEFOGLALÁS
A holland közoktatásban a tantervekről, ezek céljairól és a jövőorientált oktatásról folytatott társadalmi vitával kezdődött a tantervek - köztük a művészetpedagógiai területek tantárgyspecifikus és integratív tantárgyai - tartalmi és módszertani megújítása. A viták eredményeként helyi, regionális és kormányzati szinten egyetértés született az oktatás három fő funkciójáról: ezek a tudásszerzés, a személyiségfejlődés és a társadalmi fejlődés. A tantárgyorientált fejlesztés mellett fontos cél lesz a tantárgyak közötti koherencia erősítése és a tantárgyi kereteken átnyúló képességek fejlesztése. Alapvető feladat az is, hogy a tanulóknak a képzés során választási lehetőségük legyen. A tantervvel kapcsolatos elképzeléseket a döntéshozók részletesen megvitatták az oktatás legfőbb érdekcsoportjaival. A tanárok felvetették a tanterv szerzőségének kérdését. Ez a cikk áttekinti a rajz és kulturális tanulási területek tantervének elvi alapjait, a leginkább égető, minden műveltségterületekre vonatkozó problémákat és a fejlődés fő irányait.

A köz- és felsőoktatás szereplőivel 2017 tavaszán folytatott intenzív megbeszélések eredményeként a múvészeti és kulturális nevelés tantárgyai többé nem a "Nyelv és kultúra” területhez fognak tartozni, és a tanárok vezető szerepet kapnak a tantervi megújulásban. 2018-ban kilenc különböző munkacsoport alakul, és a pedagógusok, tanárképzők, tantervfejlesztők támogatásával fogják kidolgozni az úgynevezett "téglákat" vagy "építőköveket", a tantervek alapegységeit. Ezekből az építőelemekből fog felépülni az új tanterv a 4-18 évesek számára, 2019-ben. Ez lesz az első alkalom Hollandiában, hogy a gyakorló tanárok közvetlenül vesznek részt a tantervi reformban.
\end{abstract}

\section{ABSTRACT}

In the Netherlands, a debate is going on about the rational, aims and objectives of future-oriented education. The results will also have implications for arts and cultural education. Expert agreement on local, regional and governmental level was reached on the three key functions of education: the development of knowledge, personal development and social development. Apart from subject-oriented education the coherence between subjects and subject-transcending skills are also considered essential. Furthermore, it is a basic requirement that students should be given more freedom of choice. This rational was discussed in detail by all major

\footnotetext{
${ }^{1}$ Fordította Gaul Emil.

${ }^{2}$ Tantervfejlesztési Intézet.
} 
groups of educational stakeholders. Teachers came up with the question of ownership of the curriculum. This paper contains an overall picture of present arts and cultural education in the Netherlands, of the most pressing sector-transcending issues, and of recent developments.

After intensive consultation with the teachers' associations for the disciplines, teachers and higher education among others in spring 2017, the plans have been laid. The reform of the art and cultural education will no longer be based on the domain 'language and culture', the characteristics of the subjects in secondary education are maintained, and teachers will be in the lead at the renewal of the curriculum. In 2018, nine different working-groups - one for each subject or learning domain - consisting of teachers (primary and secondary school), teachertrainers and school-leaders supported by curriculum developers will embark on an process to develop 'bricks' or 'building blocks'. These 'blocks' will form the basis for the revision of the general curriculum (4 to 18) in 2019. This is the first time in the Netherlands that educational practice so clearly contributes to the renewal of the curriculum.

Kulcsszavak: tanterv, vizuális nevelés, tantervi követelményrendszer

Keywords: curriculum, art education, curricular requirements

\section{BEVEZETÉS}

Hollandiában a társadalom fejlődése és változásai miatt az oktatáshoz és esetünkben a müvészeti és kulturális neveléshez szükséges tudás és készségek átértékelése került az érdeklődés középpontjába. A jövőorientált nevelés értelméröl, céljáról folyik a vita, és ennek bizonyára hatása lesz a kulturális nevelésre is. A társadalmi párbeszéd egy „nemzeti ötletrohammal” kezdődött 2014-ben arról, hogy milyen oktatás kell az általános és középiskolában ahhoz, hogy tanulóink fel legyenek készítve a jövőre. A vitát széles társadalmi párbeszéd követte, amit egy, a Kulturális Minisztérium által felkért szakértői bizottság szervezett és vezetett. A bizottság 2016 elején tette közzé a beszámolóját, amelynek középpontjában az oktatás és nevelés három kulcsfeladata állt: a tudás gyarapítása, a személyes és a társadalmi fejlődés.

A tantárgyközpontú oktatáson kívül a szakértők lényegesnek tartották a tantárgyak és a tantárgyi határokon túllépő készségek közötti koherenciát. A társadalmi vitát szintetizáló bizottsági tagok úgy vélik, a diákoknak nagyobb választási szabadságot kell adni. Az eredményeket bemutatták a legfőbb érdekelteknek: a tantárgyi munkaközösségeknek, a tanulóknak és szüleiknek, hogy kiderüljön, támogatják-e ezt az elgondolást. A tanulók és szüleik úgy látták, hogy itt az ideje a tantervi revíziónak, ám az iskolavezetők és a pedagógusok a tanterv tulajdonjogának kérdésével álltak elö. A beszámolók alapján a csoportok közötti megbeszélések gyakran megegyezés nélkül végződtek. 2017 márciusában parlamenti választások voltak Hollandiában, majd új kormány alakult, és a minisztériumban mostanában dolgozzák ki az oktatáspolitikát és a tantervi reformelképzeléseket is. A döntés megalapozásához alapjaiban gondolták újra a teljes tantervet - benne a kulturális és művészeti tantervet is. Ez a teljes körü tantervi reform számos 
problémát vetett fel a 4-18 éves tanulók számára készült művészeti és kulturális nevelési tanterv kapcsán. Ez az írás napjaink hollandiai müvészeti és kulturális oktatásáról ad rövid áttekintést a leginkább szorongató, a tantárgyi területek határait átlépő, legfrissebb elképzelések bemutatásával.

\section{A HOLLAND MŰVÉSZETI ÉS KULTURÁLIS NEVELÉS JELLEMZŐI}

A holland müvészeti és kulturális nevelés egyik jellemzője a változatosság. Ez egyszerre jelent szemléletbeli, tartalmi, témabeli, terminológiai és tantervi célokat is magába foglaló sokszínűséget, ami a tanítási gyakorlatra is kiterjed. Örökös vita övezi, a 'müvészet', 'kultúra', 'kulturális nevelés' meghatározásának elméleti alapkérdéseit is.

1. táblázat. Az oktatási terület átmeneti rendelkezéseinek változatai

\begin{tabular}{|c|c|}
\hline Elemi iskola & $\begin{array}{l}\text { A kormány három képzési célt fogalmazott meg a kulturális (művészeti) } \\
\text { tantárgyak számára az alkotásról és a kulturális örökség megőrzéséről } \\
\text { egyaránt. A cél az, hogy a tanulók a vizuális kultúra széles spektrumában } \\
\text { szerezhetnek alkotói és befogadói tapasztalatokat. }\end{array}$ \\
\hline $\begin{array}{l}\text { Sajátos nevelési } \\
\text { igényü elemi } \\
\text { és középiskola }\end{array}$ & $\begin{array}{l}\text { A képzési célok: leképező ábrázolás, kézművesség, zenehallgatás, ének és } \\
\text { játékos mozgás. A képzési célok a speciális középiskolai nevelésben a diákok } \\
\text { későbbi tanulási és elhelyezkedési lehetőségeihez igazodnak. }\end{array}$ \\
\hline $\begin{array}{l}\text { Alsófokú } \\
\text { középiskola }\end{array}$ & $\begin{array}{l}\text { A „művészet és kultúra” tantárgyterületnek öt általános képzési célt tüz ki, } \\
\text { melyeket a tantárgyak saját területükön valósítanak meg. Ez az öt képzési cél } \\
\text { - amit képességterületként is meghatározhatunk - hangsúlyozza a müvészeti } \\
\text { ágak közös és sajátos nézőpontjait. A tanulók alapszinten megtanulják, } \\
\text { hogyan kell rajzolni, tárgyat készíteni, színházi produkciókban szerepelni, } \\
\text { táncolni és zenélni. }\end{array}$ \\
\hline $\begin{array}{l}\text { Alsófokú } \\
\text { szakközépiskola }\end{array}$ & $\begin{array}{l}\text { A „művészetek 1” tantárgy a tantervben előirt mind a négy képzési út } \\
\text { (tantárgycsoportos oktatás) kötelező része. A tanulók legalább négy } \\
\text { művészeti és kulturális tantárgyat tanulnak, amelyben lehetőségük van } \\
\text { alkotói és befogadói tevékenységekre is. A képzési utak két legmagasabb } \\
\text { szintjén a tanulók egy, az iskola által kínált művészeti tárgyból vizsgát } \\
\text { tehetnek. A vizuális mủvészetek, a zene, a tánc és a dráma az iskolafokozatot } \\
\text { lezáró vizsga választható része. A megújult szakképzési programban a diákok } \\
\text { az iskola kézműves tantárgyai közül is választhatnak. }\end{array}$ \\
\hline $\begin{array}{l}\text { Felsőfokú } \\
\text { középiskola }\end{array}$ & $\begin{array}{l}\text { A „kulturális és művészeti nevelés” tantárgy a felső középiskolában minden } \\
\text { tanuló számára kötelező. A választott müvészeti tárgyak régi és új típusú } \\
\text { érettségi vizsgatárgyakra oszlanak. A régi típusú vizsgatárgyak a zene, a rajz, } \\
\text { a képzőmúvészet és kézmüvesség és a textilmunkák. Az új típusú tantárgyak } \\
\text { a vizuális művészet, zene, tánc és dráma, kitekintéssel a társművészetekre - } \\
\text { ezek integratív szemléletű, „összművészeti tantárgyak”. }\end{array}$ \\
\hline
\end{tabular}


A különféle iskolaszakaszokra (1-4., 4-8., 9-12. évfolyamra) vonatkozó állami rendeletek (vö. az 1. táblázatot) magyarázzák a müvészeti és kulturális nevelésben megmutatkozó, iskolák közötti és az iskolákon belüli különbségeket. Az elemi iskolai és az alsó középiskolai szakaszra vonatkozó rendeletek az általános képzési célokra épülnek. Az iskolák joga, hogy a diákok műveltségét és képességeit fejlesztő tevékenységek közül a mono- vagy multikulturális, tantárgyi vagy interdiszciplináris tantervi megközelítést válasszák. Megtehetik, hogy számos müvészeti terület megismerésével szélesítik, vagy inkább egy területen mélyítik el a tanulók tudását. (Példa az alsó középiskolai művészet és kultúra tantárgy öt képzési célja közül az egyikre: az elemi művészeti kifejezőeszközök megismerése után a tanulók megfigyelik a különféle müvészeti ágak sajátos kifejezésmódjait, értelmezik ezek jelentését, és elsajátítják, hogyan alkalmazzák ezeket saját érzéseik kifejezésére. Az elemzés során tapasztalatokat gyüjtenek, formálódik a képzeletük és javulnak kommunikációs képességeik.)

A felső középiskolában a két rendszer egymás mellett müködik, az iskolák választhatnak a régi és az új típusú vizsgák között is. A régi típusú müvészeti tantárgyak tanterveiben (ilyen a rajz, képzőmüvészet és kézmüvesség, textil és zene) a müvészeti terület elméletére épül a gyakorlati tevékenység. Az új típusú tantárgyak (vizuális mủvészetek, zene, tánc és dráma) multidiszciplináris elméleti megközelítést alkalmaznak, a tantárgyi programok utalnak a társművészetekre is. A felső középiskolások az iskolában kínált tárgyak közül választhatnak egy mủvészeti tantárgyat, amelyből majd vizsgázni fognak. A gyakorlati tantárgy részből iskolai, az elméleti részből pedig központi vizsgát kell tenniük.

A vizsgakövetelmények nagyban befolyásolják a tantárgyak tartalmát, de az elemi iskolai művészeti és kulturális nevelés iskolánként azért is lehet nagyon különböző tartalmú és minőségű, mert a pedagógusok felkészültsége erősen eltérő ezen a területen. A különbségek csökkentésére számos továbbképző tanfolyamot szerveztek például a tanítók művészetpedagógiai módszereinek fejlesztésére. A képzések nyomán nő a müvészeti képzettséggel is rendelkező alapfokú oktatók száma. A középfokú oktatásban (tizenegy éves kortól) már szaktanár oktatja a müvészeti és kultúrális nevelés müveltségterületet. Vannak „kulturális tagozatos” iskolák, ahol nagyobb figyelmet fordítanak a müvészetpedagógiára, például a vizuális nyelvet a többi tantárgy oktatásába is beépítik. A tanárképző intézményeknek minden múvészeti ágban van mesterszakos képzése.

A holland iskolák tantervi autonómiája a müvészeti és kulturális tantárgyak szempontjából több tanítási, tanulási programvariációt eredményezett. Ezek más és más elméleti alapon állnak, például a befogadásra orientált müvészettel nevelés (arts education), a kognitív fejlesztésre fókuszáló müvészetalapú tanulás (arts-based learning) és a személyiségfejlesztést előtérbe helyezö tanulás a müvészet által (education through art). Az iskolák a müvészet és kulturális nevelés tantárgyat 
illetően saját oktatási-nevelési céljaik, társadalmi-pedagógiai missziójuk alapján döntenek. A müvészeti képzés színvonala változó, csakúgy, mint a rá irányuló figyelem. Az egyre magasabb iskolatípusokban azonban egyre nagyobbak a müvészeti tárgyak vizsgakövetelményei, így a vizsgatárgyakat választó tanulók egyre többet sajátítanak el a müvészeti kultúrából.

\section{A KÉPZÉSI TERÜLETEK ÉS A TANTÁRGYAK HATÁRAINAK ÁTLÉPÉSE}

A jelenleg zajló tantervi reform várhatóan lehetőséget teremt arra, hogy mi, tantervszerkesztők megjelenítsünk néhányat az alább részletezett, több mủveltségi területen lényeges alapismeretek közül.

\section{Hiányoznak a közös elméleti alapok}

A többféle müvészeti és pedagógiai elképzelés, vízió és ezek interpretációi, valamint a viszonylag kötött vizsgaprogramok és az iskolák autonómiája közötti ellentét arra ösztönzik a müvészetpedagógusokat, hogy megteremtsék a művészeti és kulturális nevelés mủveltségterületének közös elméleti alapjait. Annál is inkább ez a feladatuk, mert a tanároknak naprakész tananyaggal kell rendelkezniük, csökkenteniük kell a túlterhelést, koherens tananyagot kell létrehozniuk, és a képzési területek között kapcsolatokat teremtö tantervet kell kidolgozniuk. A tanároknak nincs nagy gyakorlatuk a tantervírásban, és nincs is elég idejük a tanítás mellett az iskolai autonómia részét képező, saját tanterv kidolgozására.

\section{Az egyes iskolaszakaszok, valamint a régi és az új típusú képzés között nem elég erős a koherencia}

Úgy tűnik, a pedagógusokat nehéz feladat elé állítja az elemi iskolától a középiskoláig tartó koherens és folyamatos tantervi programok kidolgozása. Az 1. táblázatból látszik, hogy a művészeti és kulturális nevelésben jelentős a szakadék az elemi iskola és az alsófokú középiskola általános képzési követelményei között. Hasonló szakadék van az alsó és a felső középiskola kimeneti követelményei között is. Továbbá, a „régi típusú” vagy „új típusú” mủvészeti nevelési programot megvalósító iskola az eltérö tantervi utakból adódóan meghatározza a tanulói képességek fejlődését is. Az utóbbi néhány évben a legtöbb figyelmet az iskolaszakaszokon belüli fejlödés kapta, a tantervi utak kevesebbet. Ez azt eredményezte, hogy nem mindegyik tanulónak volt megfelelö tudásalapja, hogy az egyik tantervi útról, az egyik iskolatípusból áttérjen a másikba. 


\section{Az új koncepciók megkövetelik a képzési célok megújitását}

A felső középiskolai vizsgakövetelményektől eltekintve, 2006, a legutóbbi nagy tantervi reform óta a képzési célok nagymértékben átalakultak. A müvészeti és kulturális nevelés világa a technikai fejlődés következtében állandó mozgásban van. Ez a mozgás új mủvészetfelfogásokhoz és multimediális múvészetképhez vezetett, ami viszont hatással volt a kulturális produktumok elóállítására és fogyasztására is, valamint a társadalomban betöltött szerepére. Íme, néhány az új jelenségek közül, amelyekkel foglalkoznunk kell az iskolában is. Új jelenség például a fizikai tér mellett megjelenő virtuális világ, ahol „sétát tehetünk” például egy múzeumban, vagy „,meglátogathatunk” egy müemléket.

Egyre nő az érdeklődés napjainkban a fesztiválok és más kulturális események iránt is. Mindez oda vezetett, hogy az új, vizualitás iránt érdeklődő társadalom tagjának lenni új képességeket igényel. Manapság a tanulók már egész kis koruktól kezdve, egyre komplexebb jelentésủ audiovizuális médiával és vizuális kifejezési formákkal kerülnek kapcsolatba. Emellett egyre növekvő igény mutatkozik a kreativitásra, és ebből következően, a müvészeti és a kulturális nevelés során elérhető kreativitásfejlesztési lehetőségek iránt is nő a társadalmi igény. Ezek az új lehetőségek és igények határozzák meg, mi módon és milyen mértékben kell a jelenlegi művészeti és kulturális tantervet korszerüsíteni.

\section{LEGFRISSEBB FEJLEMÉNYEK}

A holland iskolarendszerről ma az a vélemény alakulhat ki, hogy a mủvészeti és kulturális nevelés csak mint „alapszintű szolgáltatás” müködik. Különféle területeken azonban jelentős erőfeszítések történnek. Például az elemi iskolai mủvészeti és kulturális nevelés színvonalának emelése érdekében egy mintaszerű tantervfejlesztési programban közös müvészetpedagógiai képzési célokat dolgoztak ki. A zeneoktatás területén „Több zenét az osztályterembe” jelszóval, új módszereket vezettek be. Az új vizsgarendszerben az alsó középfokú szakközépiskolában lehetőség nyílt a kézmüvesség oktatására fotó, illusztráció, divat és design szakirányban. A felső középiskolai művészeti és kulturális nevelés vizsgarendjét is módosították. Azonban, mint korábban már említettük, az oktatási rendszerben az egyes szintek nem illeszkednek kellőképpen egymáshoz. A kérdés ma az, hogy mit tegyünk egy sokkal szilárdabb tantervi szerkezet megalkotása érdekében.

Néhány tanulságot már most is levonhatunk a tantervváltoztatási folyamatból. A bevezetőben említett minisztériumi szakértői jelentés nemcsak az oktatás céljaira fókuszált („mit kell elsajátítania a tanulónak napjaink közoktatásában?”), hanem bizonyos tantárgyak tartalmára és tantervi helyére is javaslatot tett. Azt indítványozták, hogy a meglévő, autonóm tantárgyak sorát megjelenítő struktúrát 
alakítsuk át müveltségterületek szerinti csoportosításra, amely jobban hangsúlyozza majd a tantárgyak közötti koherenciát. Ennek megfelelően az összes müvészeti és kulturális tantárgyat a „nyelv és kultúra” területhez sorolták, ami vitát váltott ki a tanárok között, és zürzavarhoz vezetett. Az eddig autonóm tantárgyi munkaközösségek és a tanárok maguk sem tudtak azonosulni a javaslat tartalmával, és úgy érezték, hogy feleslegesen osztották meg a bizottság tagjaival a véleményüket. Az országos tantervi reform legnagyobb tanulsága, hogy a tanárokat a lehető leghamarabb be kell vonni a reform munkálataiba. A holland tanárok hangsúlyozták, hogy ők akarnak a tantervírási folyamat tulajdonosai lenni, és mielőbb be is akarják tölteni ezt a szerepet.

A tantárgyi munkaközösségekkel, az egyes pedagógusokkal és a felsőoktatás szereplöivel 2017 tavaszán folytatott intenzív megbeszélés során kiélesedett a vita, amelynek eredményeként a müvészeti és kulturális nevelés tantárgyai többé nem a „nyelv és kultúra” területhez fognak tartozni, a tantárgyak korábbi karakterét a felső középiskolában megtartják, és a tanárok vezető szerepet kapnak a tantervi megújulásban. 2018-ban kilenc különböző munkacsoport alakul - a tantárgyaknak és müveltségterületnek megfelelően -, ami elemi és középiskolai szinten tanító pedagógusokból, tanárképzési szakemberekből és iskolavezetőkből fog állni. A munkacsoportokat tantervfejlesztők támogatják majd. Ezek a csoportok fogják kidolgozni az úgynevezett ,téglákat” vagy „,építőköveket”, a tantervek alapegységeit. Ezekből az építő elemekből fog felépülni az új tanterv a 4-18 évesek számára 2019-ben. Ez lesz az első alkalom Hollandiában, hogy a gyakorló tanárok közvetlenül vesznek részt a tantervi reformban. 